This is an author produced version of a paper published in Scandinavian Journal of Forest Research.

This paper has been peer-reviewed but may not include the final publisher proof-corrections or pagination.

Citation for the published paper:

Lars Drössler, Rolf Övergaard, Per Magnus Ekö, Pelle Gemmel, Henrik Böhlenius. (2015) Early development of pure and mixed tree species plantations in Snogeholm, southern Sweden. Scandinavian Journal of Forest Research. Volume: 30, Number: 4, pp 304-316. http://dx.doi.org/10.1080/02827581.2015.1005127.

Access to the published version may require journal subscription. Published with permission from: Taylor \& Francis.

Standard set statement from the publisher:

This is an Accepted Manuscript of an article published by Taylor \& Francis Group in Scandinavian Journal of Forest Research on 30/01/2015, available online: http://www.tandfonline.com/ 10.1080/02827581.2015.1005127

Epsilon Open Archive http://epsilon.slu.se 


\section{Early development of pure and mixed tree species plantations in Snogeholm, southern Sweden}

Lars Drössler, Rolf Övergaard, Per Magnus Ekö, Pelle Gemmel, Henrik Böhlenius

Southern Swedish Forest Research Centre, SLU, Rörsjövägen 1, SE-23053 Alnarp, Sweden

\section{Abstract}

To assess general effects of tree species mixtures on forest production, in 1994 an experiment was established in an afforestation landscape in southern Sweden with 66 plots: 18 planted with single trees species (including most native Swedish trees, plus Populus and Larix hybrids) and 48 with various non-replicated mixtures. Fifteen years after planting, growth was analyzed in these plots. Production varied substantially among the monocultures, while the mixtures had grown more evenly and moderately (particularly mixtures of more than two species). Detailed comparison of mixtures containing Picea abies or Quercus robur with their monocultures indicated that admixture of these species has positive and negative effects, respectively, on early production, and admixture of pioneer/nurse tree species had no significant positive effect, except when using pooled data for mixtures and monocultures of late-successional or intermediate tree species. In addition no consistent differences in the mean height and mean diameter growth of Picea abies and Quercus robur between mixtures and monocultures were detected. A major conclusion is that adding more than two species did not increase volume growth.

Keywords: southern Sweden, mixed forest, monoculture, stand volume production, height growth, early development

\section{Introduction}

Mixed forests have several widely recognized advantages over monocultures, including greater resilience (Bolte et al. 2009, Hantsch et al. 2013, Hulvey et al. 2013), biodiversity (Felton et al. 2010) and aesthetic appeal. Some authors have also argued that mixed forests are generally more productive than monocultures (Vandermeer 1989, Nadrowski et al. 2010, Hulvey et al. 2013). However, effects of mixtures on growth rates are complex, and linked to effects of facilitation and competition among tree species (see Kelty 1992, Pretzsch 2009) associated (for instance) with ecologically important traits such as nitrogen-fixation (Richards et al. 2010, Pretzsch 2013, Forrester 2014). Furthermore, few experimental studies have compared production rates in mixed stands and monocultures. Pretzsch et al. $(2010,2013)$ found that Norway spruce and oak species had complementary relationships with European beech in mixed forest experimental plots spread across a wide nutrient-richness gradient in Central Europe, as mean productivity was ca. $20 \%$ higher in the mixed stands than in the monocultures.

There have been no previous experimental comparisons of the productivity of mixed stands with corresponding monocultures at the same site in the northern temperate forests of Sweden. However, attempts have been made, for instance by Agestam (1985), to estimate growth rates of 
mixed pine-birch and spruce-birch stands using specifically developed models. In addition, using Swedish National Forest Inventory data Gamfeldt et al. (2013) found indications that tree species richness promotes the growth of forests in Sweden, and concluded that biomass production is generally ca. $50 \%$ greater in mixed forests than in forests with a single tree species. Although comparison with other studies is difficult, as site conditions may vary between mixed and pure forests, the magnitude of the apparent mixing effect on production is surprising as both estimates by growth models (Agestam 1985, Mielikäinen 1985) and observations from single experiments at the same site (Jonsson 2001, Fahlvik et al. 2011) report just 0-15\% growth differences. Nevertheless, the estimates by Gamfeldt et al. (2013) substantially raised awareness of the improvements in productivity that mixed plantations could potentially deliver, and thus may promote their establishment in the future.

The purpose of the study reported here was to compare the early growth of plantations with various mixtures of tree species and corresponding monocultures in an afforestation landscape laboratory in Snogeholm, southern Sweden, with 66 experimental plots: 18 planted with single trees species (including most native Swedish trees, plus Populus and Larix hybrids) and 48 with various mixtures. In addition, the landscape laboratory contained one plot seeded with a single tree species, and two plots not afforested. The overall aim of the laboratory, designed and established cooperatively by forest researchers and landscape architects (Nielsen 2011), was to identify ways to meet various combinations of recreational, timber production and biodiversity requirements. From a management perspective, the main objectives were to demonstrate various stand types and forest structures, and develop appropriate silvicultural practices (choice of tree species, mixtures, thinning regimes and rotation periods) for establishing and maintaining them. Today, the stands are frequently used for demonstration, education and recreation.

The experimental design is not completely randomized and includes no replicates. However, given the paucity of empirical comparisons of mixed and pure stands on the same site the experiment provides the opportunity to gather sufficient independent observations and inventory data to extend understanding of productivity in mixed forest stands, which has been largely based to date on modelling and general inferences. Thus, the paper represents a single-site investigation of the degree (if any) to which tree species richness influences stand productivity. For the given time window and study site we tested one a posteriori hypothesis: that forest production increased with increasing number of tree species. In addition, we addressed the question if the risk of failure to establish forest was higher in monocultures.

\section{Materials and methods}

\section{Experimental site and design}

The study site covers 30 ha, $40 \mathrm{~km}$ east of Malmö ( $55^{\circ} 32^{\prime} 55^{\prime \prime} \mathrm{N}, 13^{\circ} 42^{\prime} 15^{\prime \prime} \mathrm{E}, 50-60 \mathrm{~m} \mathrm{ASL}$ ), used as agricultural cropland before initiation of the experiment in 1994. The site is located in a slightly hilly landscape, but quite flat (with a gentle slope in one part of the planted area), fertile and suitable for most of the tree species planted in Sweden, although pine and birch are typically cultivated on less fertile soils. The soil is a well-drained brown earth on glacial till, the mean annual 
temperature is about $7.5^{\circ} \mathrm{C}$, and mean annual precipitation is $700-800 \mathrm{~mm}$ (SMHI 2009). The growing season (number of days with mean temperature above $5^{\circ} \mathrm{C}$ ) lasts ca. 220 days (Nielsen 1996).

In spring 1994, 67 forest stands were established with sizes of 0.25-0.5 ha and unique tree species compositions. The areas selected for planting were not fully randomized, because oak, beech, ash, cherry and the included conifer species were assigned to areas that hosted them to promote longterm development of mature stands dominated by these target species. Thus, clumped segregation in five areas was used to establish the experiment, thereby violating the principle of interspersion according to Hurlbert (1984). Within these areas, the locations of mixed and pure stands were randomly assigned (Figure 1). In 18, 35 and 13 stands, one, two and three or more species were planted, respectively (Table 1). In every stand, permanent study plots, with areas ranging from 781 to $1407 \mathrm{~m}^{2}$, were established, each separated from other stands or open land by a $10 \mathrm{~m}$ buffer zone. An aerial view of the landscape laboratory is presented in Loginov (2012).

Various types of planting stock and seed sources (Table S2, Supplementary Information) as well as treatments were applied in establishment of the stands. However, for our analysis of mixed and pure forests, we considered only two treatments: 1) monoculture, and 2) mixed forest. Previously defined treatments were classified in these terms a posteriori (see Table 1) to allow the mixed plots containing given species to be treated as pseudoreplicates (Hurlbert 1984) and apply inferential statistics to compare the plots generally as mixed forest and monocultures.

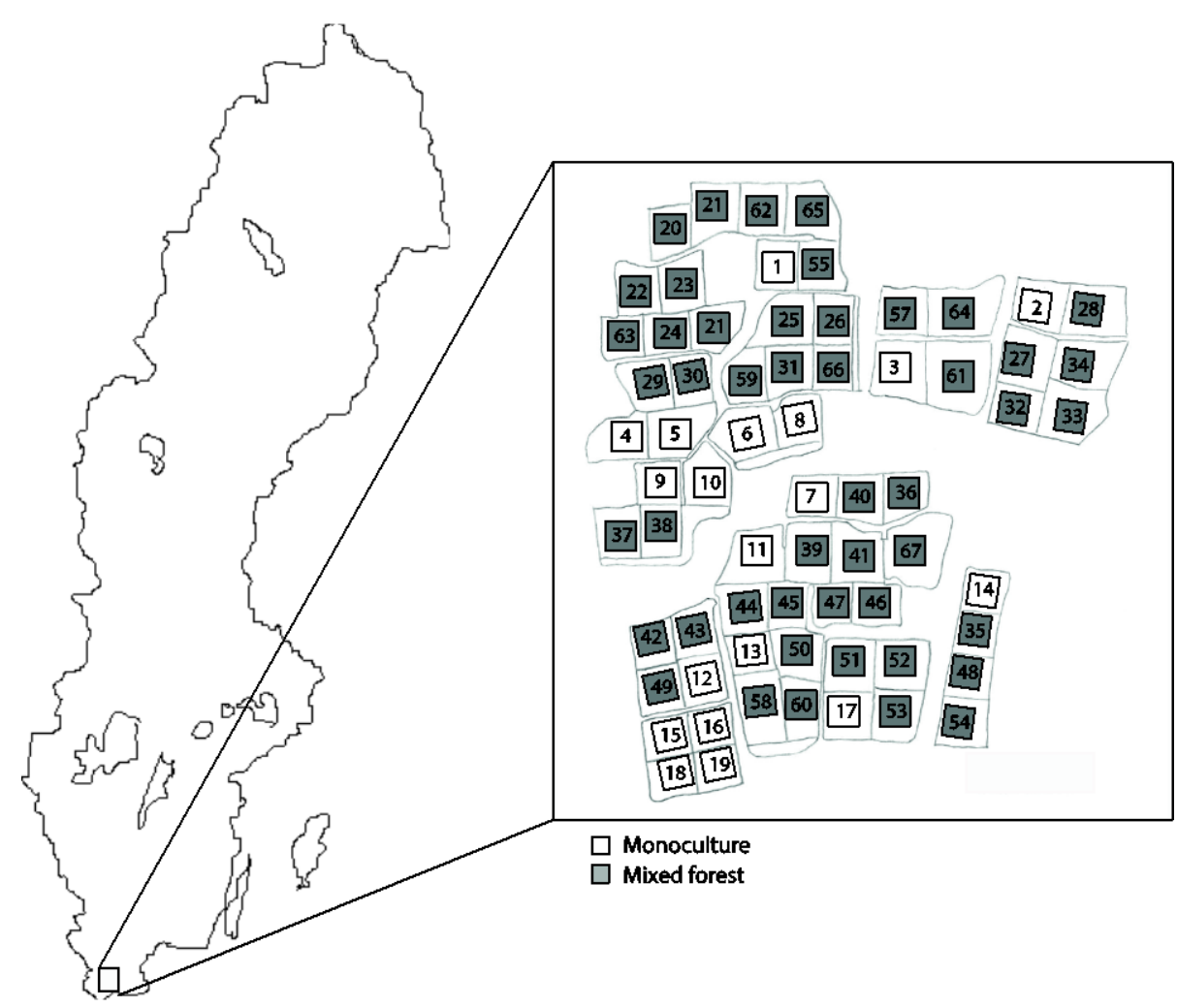

Figure 1. Map of the study site with mixed forest types (grey) and monocultures (white). The numbers refer to the forest types and tree species compositions described in Table 1. 
<<<Table 1 near here»>>

Establishment

The planting densities ranged from 1600 to 6800 plants per ha (with averages of 3494, and 3642 per ha in monocultures and mixtures, respectively, and 3600 per ha overall). All mixtures were planted with single tree species in rows, except for pedunculate oak, which was planted in groups in all cases but one. The summers in 1994 and 1995 were very dry, so in both of these years some irrigation was applied in spring and summer. Nevertheless, drought caused an overall mortality of $7 \%$ during the first summer after planting, and there was a similar mortality rate during the second year, largely due to grazing by voles. Consequently, replacement planting was conducted in 1995 and 1996. After the second replacement planting, overall mortality decreased. Five years after the initial planting and unusually strong efforts to establish the stands they contained $96 \%$ of the intended number of saplings, on average, and 15 years after planting numbers of survivors and replanted trees were approximately $80 \%$ of the numbers of planted seedlings ( $76 \%$ in mixtures, $89 \%$ in monocultures). Including natural mortality and management removals, a third of the initially planted trees were removed during the observation period. Based on the tree densities recorded five years after planting, natural mortality during the last 10 years amounted to $16 \%$ on average ( $17 \%$ in mixed stands and $12 \%$ in monocultures).

Provenances and sizes of the planting stock are described in Table S2 (Supplementary Information). After 15 years many stands had been thinned 1-3 times. Thinning removals were often more frequent and lighter than in standard forestry practice.

\section{Measurements and data analysis}

The initial numbers of seedlings in the study plots were estimated from records of numbers planted in spring 1994. In autumn 1994 and 1995, the survival rate of each species was recorded in each stand in order to replace dead plants with new plants. Additionally, the number of trees in nine 10 $\mathrm{m}^{2}$-sample plots in every stand was recorded in autumn 1998.

Ten and 15 years after planting, diameters of plants of all target species were cross-callipered at a height of $1.3 \mathrm{~m}$ in all permanent study plots, and in each plot the height of at least 30 sample trees was measured, including at least 10 trees of each species. Species-wise secondary height functions were then estimated, and their standing volumes were calculated using the functions presented in Table 2. Tree removals were recorded at the time of thinning.

<<<Table 2 near here»>>

The growth analysis included 22 comparisons of mixed and pure stands (Table 3), including comparisons of total volume production in them (cf. Kelty 1992, p. 126-127). In addition, total volume production was adjusted to account for the positive correlation between growth rates and stand density (Petterson 1992, Rio and Sterba 2009). 
137 To assess effects of stand density on production, the relationship described by Petterson (1992) for

138 Norway spruce (Figure 2) was used to analyze the sensitivity of the results without correcting for

139 stand density. The stand-wise growth comparisons were complemented by total wood biomass

140 production estimates for mixed and pure stands calculated using the wood densities of tree species

141 listed in Table 4.

142

143 Table 3. Overview of the comparisons between mixed and pure forest stands made in this study.

\begin{tabular}{|c|c|c|c|}
\hline Growth parameter & Comparison & Group 1 & Group 2 \\
\hline \multirow{7}{*}{ Total stand production } & 1 & All mix & All mono \\
\hline & 2 & All mix without ash & All mono without ash \\
\hline & 3 & All mix without hybrids & All mono except hybrids \\
\hline & 4 & $\begin{array}{l}\text { All mix with spruce, oak, beech, larch, } \\
\text { cherry and lime exclusively }\end{array}$ & $\begin{array}{l}\text { Mono of spruce, oak, beech, larch, cherry } \\
\text { and lime exclusively }\end{array}$ \\
\hline & 5 & All mix without pioneer/nurse species & All mono without pioneer/nurse species \\
\hline & 6 & $\begin{array}{l}\text { All mix of pioneer/nurse species (alder, } \\
\text { birch, aspen, larch) with climax tree species } \\
\text { (beech, oak, spruce, lime, hornbeam) }\end{array}$ & $\begin{array}{l}\text { All mono of pioneer/nurse species or climax } \\
\text { tree species (same species as in group 1) }\end{array}$ \\
\hline & 7 & $\begin{array}{l}\text { All mix of pioneer/nurse species with } \\
\text { climax tree species }\end{array}$ & $\begin{array}{l}\text { All mono AND mix of pioneer/nurse species } \\
\text { and all mono AND mix of climax tree species }\end{array}$ \\
\hline Density-corrected total stand production & 8 & All mix & All mono \\
\hline Stem biomass production & 9 & All mix & All mono \\
\hline \multirow{2}{*}{ Tree species specific growth } & 10 & All mix with spruce & Spruce mono \\
\hline & 11 & All mix with oak & Oak mono \\
\hline \multirow{4}{*}{ Dominant height } & 12 & All mix with spruce & Spruce mono \\
\hline & 13 & All mix with oak & Oak mono \\
\hline & 14 & All mix with beech & Beech mono \\
\hline & 5 & All mix with birch & Birch mono \\
\hline \multirow{4}{*}{ Mean height } & 16 & All mix with spruce & Spruce mono \\
\hline & 17 & All mix with oak & Oak mono \\
\hline & 18 & All mix with beech & Beech mono \\
\hline & 19 & All mix with birch & Birch mono \\
\hline \multirow{2}{*}{ Mean diameter } & 20 & All mix with spruce & Spruce mono \\
\hline & 21 & All mix with oak & Oak mono \\
\hline
\end{tabular}

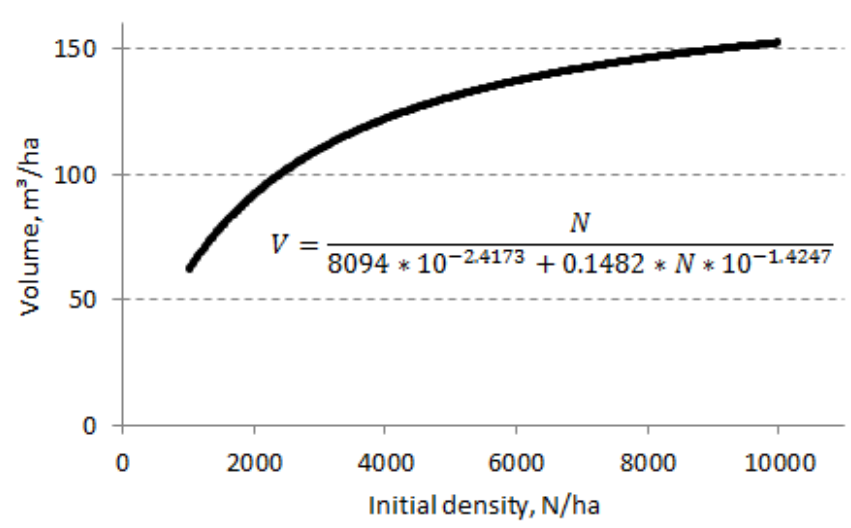

148 Fig. 2. Relationship between initial planting density $(\mathrm{N})$ and volume growth $(\mathrm{V})$ of Norway spruce plantations at $10 \mathrm{~m}$ dominant height, according to Petterson (1992) 
$<<<$ Table 4 near here $>>$

Secondly, growth of the two most common tree species, pedunculate oak and Norway spruce, in pure and mixed stands was compared (cf. Pretzsch 2009, pp. 352-354). The proportion of area covered by each of the admixed species in the mixed plots was estimated on the basis of the proportions of individuals originally planted. Additionally, the proportion was also estimated by the basal area proportion of each admixed species at age ten after thinning in order analyze the sensitivity of our results.

Differences in volume and biomass production between several monocultures and mixtures were examined using Student's 2-tailed two-sample t-test. Both the single sample t-test (assuming population means are known) and the two-sample t-test (assuming equal variance of the sample groups) were used when testing for significant differences between a single observation of mean and dominant height of a given tree species in a pure stand with observations in several mixtures. The confidence level was set to $95 \%$.

\section{Results}

Stand volume production

No significant difference was detected in average growth between pure and mixed stands. Average standing volumes 15 years after planting were 111.5 and $119.8 \mathrm{~m}^{3} \mathrm{ha}^{-1}$ in these stands, respectively. However, the standard deviation was considerably lower in mixed stands $\left(52.8 \mathrm{~m}^{3} \mathrm{ha}^{-1}\right)$ than in monocultures $\left(85.2 \mathrm{~m}^{3} \mathrm{ha}^{-1}\right)$, as standing volumes in monocultures, mixtures with two species and mixtures with >2 species ranged from 9 to $279 \mathrm{~m}^{3}, 11$ to $280 \mathrm{~m}^{3} \mathrm{ha}^{-1}$, and 53 to $161 \mathrm{~m}^{3} \mathrm{ha}^{-1}$, respectively. Thus, increases in numbers of species resulted in more even, and moderate production (Figure 3). Production was very high in mixed hybrid aspen-Norway spruce and hybrid larch-Norway spruce stands, and very low in mixed wild cherry-European ash and European ash-wild maple stands (which suffered from ash dieback).

No significant differences in growth were found between monocultures of Norway spruce, pedunculate oak, European beech, hybrid larch, wild cherry or small-leaved lime and mixtures containing them, or between mixtures of either light-demanding or shade-tolerant species and monocultures of the species. Significantly lower growth rates in mixtures were only detected in a separate comparison of mixtures including spruce with the corresponding monocultures. When pioneer species were excluded, no significant differences at all between monocultures and mixtures were detected (Table S3, Supplementary Information). Furthermore, significant differences were only detected in comparisons of monocultures of late-successional tree species and mixtures containing them and a pioneer or nurse species (Table S5). No significant differences were found in comparisons of mixtures of pioneer/nurse tree species and late-successional species with pure stands of these species (mean total production: 167 and $146 \mathrm{~m}^{3} \mathrm{ha}^{-1}$, respectively). 


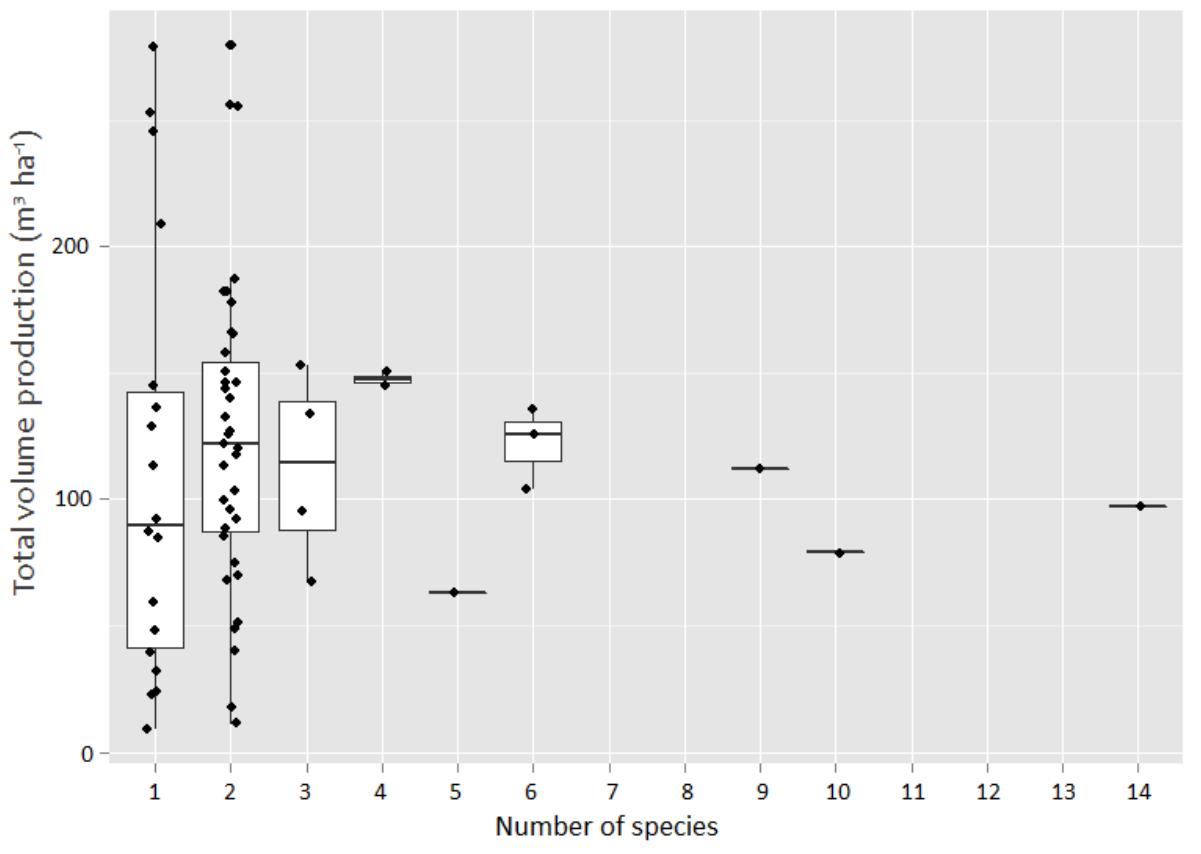

187 Fig. 3. Total stem volume production during the first 15 years after planting in stands with indicated numbers of tree species. Some mixtures contained shrub species (see Supplementary Information). Boxes indicate the first and third quartile of data, whiskers indicate either 1.5 times the interquartile range or the maximum/minimum value of production.

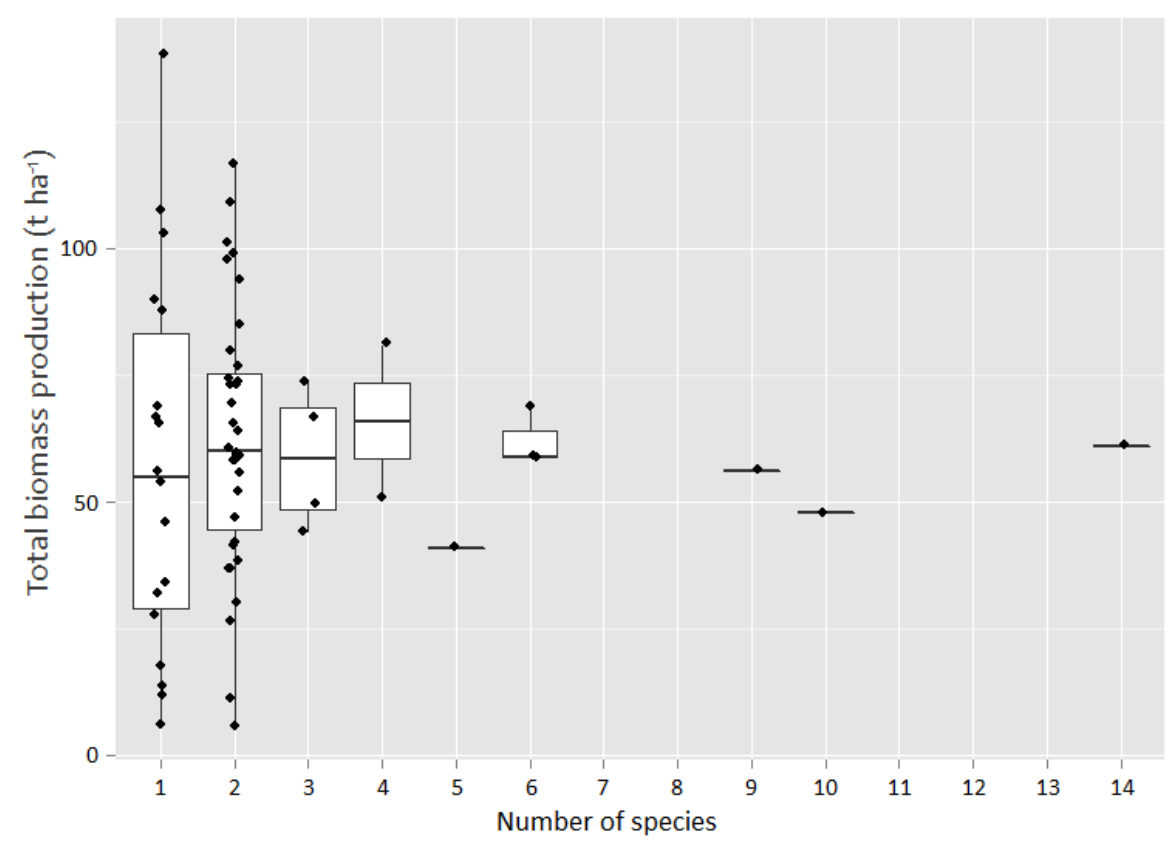

193 Fig. 4. Total estimated dry stem biomass production during the first 15 years after planting in stands with indicated numbers of tree species. Boxes indicate the first and third quartile of data, whiskers indicate either 1.5 times the interquartile range or the maximum/minimum value of production. 
As shown in Figure 4, no significant differences were found in estimated dry stem biomass production between monocultures and mixed stands ( 57 and $62 \mathrm{t} \mathrm{ha}^{-1}$, respectively). Furthermore, following density-based growth correction according to Petterson (1992), average production was identical (123 $\mathrm{m}^{3} \mathrm{ha}^{-1}$ ) in monocultures and mixtures (Figure 5), as the correction increased the production maxima for stands with one or two tree species and relatively low planting densities, but had little effect on the production values for mixtures of three or more tree species. The correction also increased the standard deviation more for monocultures (from 85 to $106 \mathrm{~m}^{3} \mathrm{ha}^{-1}$ ) than for mixtures ( 53 to $60 \mathrm{~m}^{3} \mathrm{ha}^{-1}$ ).

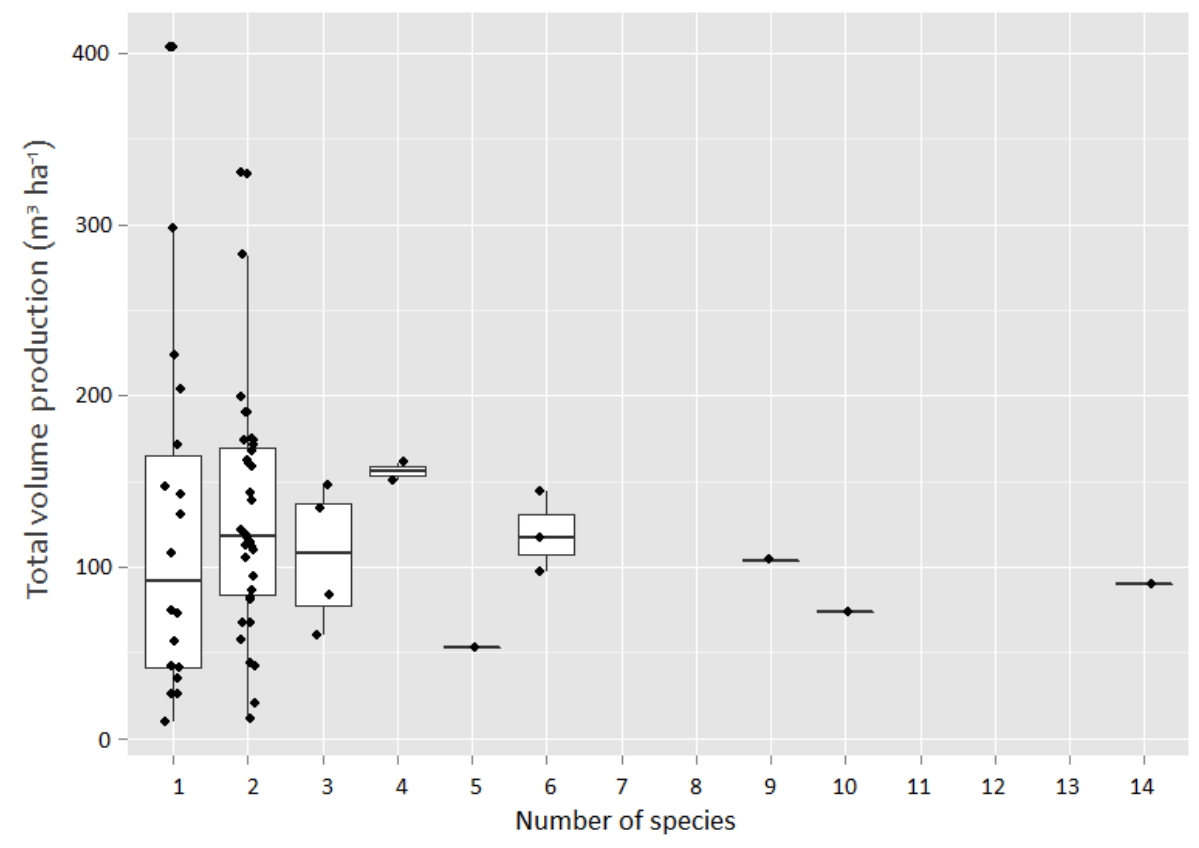

Fig. 5. Total stem volume production during the first 15 years after planting in stands with indicated numbers of tree species, following correction to account for variations in initial stem density (Petterson 1992). Boxes indicate the first and third quartile of data, whiskers indicate either 1.5 times the interquartile range or the maximum/minimum value of production.

Comparison of the volume production of mixtures including Norway spruce or pedunculate oak and their monocultures

Figure 6 shows the volume production of Norway spruce mixtures in comparison to monocultures, expecting equal growth rates for each tree species as in corresponding monocultures (tree species proportions estimated by initial tree number). The production of Norway spruce mixtures was $15 \%$ lower $\left(178 \mathrm{~m}^{3} \mathrm{ha}^{-1}\right)$, on average, than the Norway spruce monoculture $\left(209 \mathrm{~m}^{3} \mathrm{ha}^{-1}\right)$. The expected growth for the different tree species in these mixtures according to their growth in corresponding monocultures was $4 \%$ lower on average, but ranged from $34 \%$ lower to $21 \%$ higher. Figure 7 shows the volume production of mixtures with pedunculate oak which was $23 \%$ higher $\left(107 \mathrm{~m}^{3} \mathrm{ha}^{-1}\right)$, on average, than the oak monoculture $\left(87 \mathrm{~m}^{3} \mathrm{ha}^{-1}\right)$. The expected growth for the different tree species was $8 \%$ higher on average in mixtures than in corresponding monocultures (ranging from $40 \%$ lower to $51 \%$ higher). If the expected growth was estimated by the basal area proportions at age 10 , the differences between expected and observed growth increased 


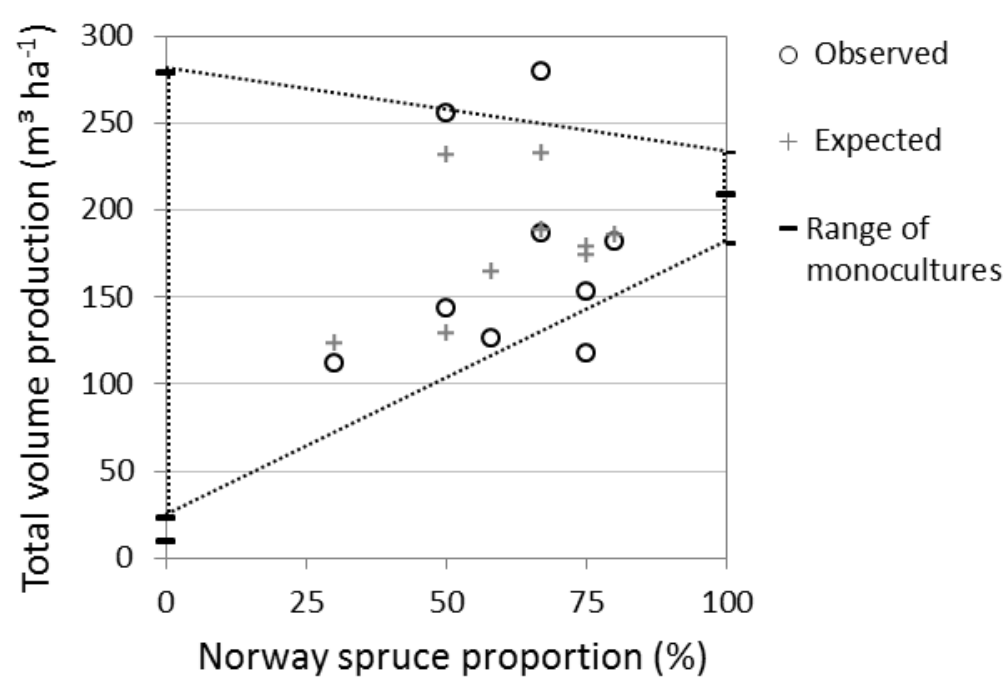

222

223 Fig. 6. Comparison of observed total volume growth of Norway spruce mixtures and expected growth based on the proportions of tree species, assuming that growth rates of the admixed tree species were the same as in the corresponding monocultures. The large range for monocultures with no spruce reflects the extremely low production of ash and rowan, and extremely high production of hybrid aspen, observed in this field study. The smaller range for the spruce monoculture indicates the expected range if the single spruce monoculture had been planted elsewhere in the trial site, where site indices may have been one class higher or lower.

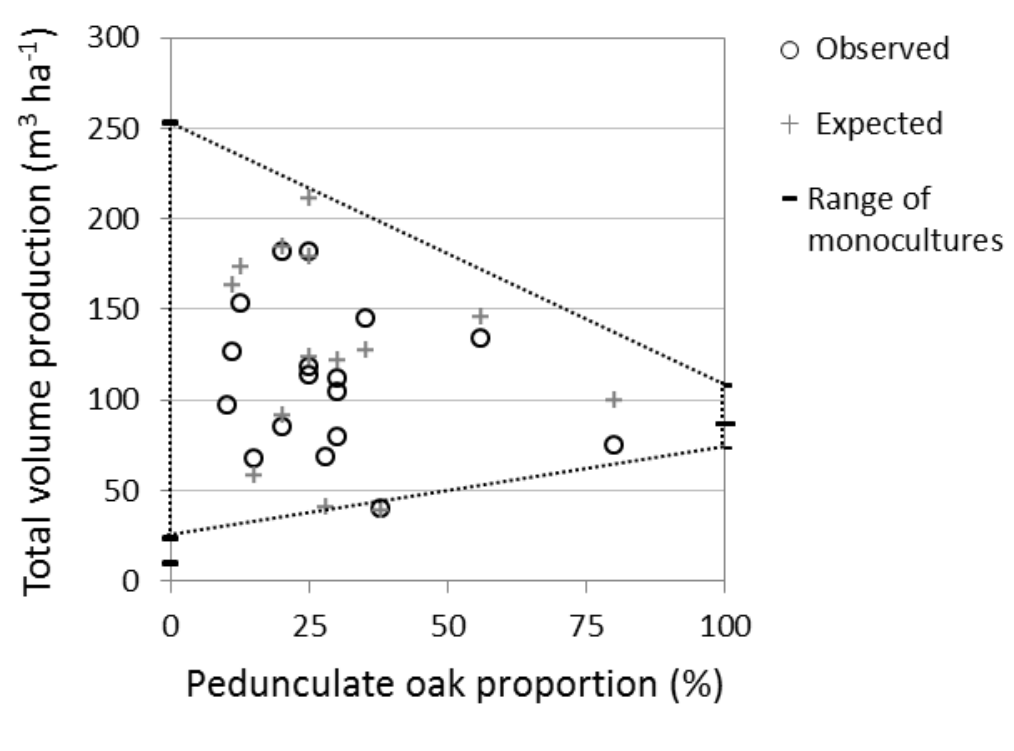

232 Fig. 7. Comparison of total volume growth of pedunculate oak mixtures and expected growth based on the proportions of tree species present, assuming that growth rates of the admixed tree species were the same as in the corresponding monocultures. The large range for monocultures with no spruce reflects the extremely low production of ash and rowan, and extremely high production of hybrid aspen, observed in this field study. The much smaller range for the oak monoculture indicates 
the expected range if the single oak monoculture had been planted elsewhere in the trial site, where site indices may have been one class higher or lower.

Diameter and height growth of Norway spruce and pedunculate oak

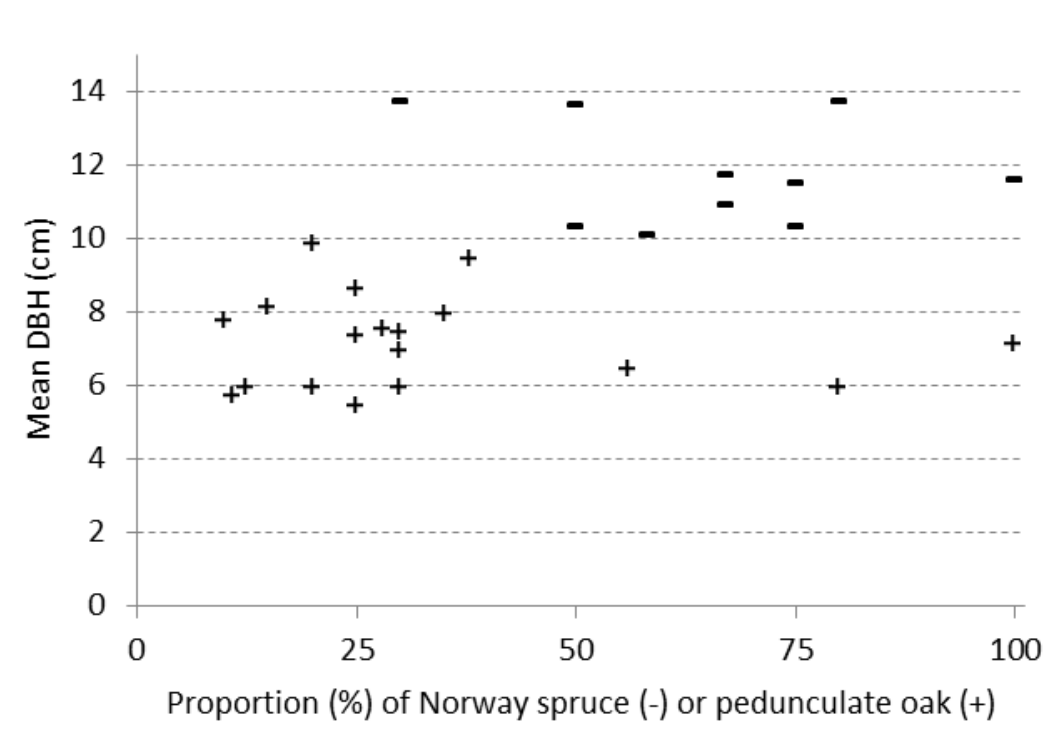

Fig. 8. Mean diameter of Norway spruce and pedunculate oak 15 years after planting, as a function of their proportions in the stands

The diameter of trees in mixed stands containing the two species of spruce and oak were similar or smaller than in the monoculture. No significant differences between the size of trees in mixtures and monoculture were found. However, the variation of the mean diameters of oak was higher with low proportions of the tree species (Figure 8).

At the end of the observation period, the dominant heights of spruce were significantly lower in mixtures than in the pure stands. The mean heights of spruce and oak were also significantly lower in mixed stands than in their respective monocultures (Table S4).

\section{Discussion}

Stand volume production

Our results indicate that production rates during early stand development generally become more even, and moderate, as the number of tree species present increases, as shown by the stem volume and stem biomass estimates in Figures 3 and 4. Correction for variations in densities of the stands included in the study does not affect this major conclusion. Clearly, there was no consistent increase in production with increasing numbers of tree species, contrary to expectations based on fundamental ecological theories (Vandermeer 1989) or data from grassland experiments (Isbell et al. 2011). Indeed, no significant differences in production were found between mixed and pure 
stands, even when stands containing ash (which was affected by dieback) or pioneer trees species were excluded (Table S3, Supplementary Information). Thus, our results indicate that early growth of a stand containing a productive tree species cannot be increased merely by admixing less productive tree species. However, the results also show that the mixing effect depends on the tree species composition (Figures 4 and 5). For instance, when Norway spruce was mixed with pedunculate oak the production level was intermediate between that of the two species, and in oak-spruce bicultures, total stand production was a third lower than in the spruce monoculture (138 vs. $209 \mathrm{~m}^{3}$ $\mathrm{ha}^{-1}$ or $63 \mathrm{vs.} 90 \mathrm{t} \mathrm{ha}^{-1}$; Figures 6 and 7), although this was presumably mainly due to extensive removal spruce in order to free the oaks from competition. This single observation corroborates findings by Saha et al. (2012) from observations at multiple sites in Central Europe.

As expected, the type(s) of admixed tree species strongly affected the mixing effect. For example: the growth increased when spruce was mixed with fast-growing hybrid aspen or hybrid larch (Figure 6); mixed stands including oak grew more rapidly than the oak monoculture (Figure 7); and stands containing more than two species grew substantially more slowly than the fastest growing monocultures and bi-cultures. The general trend for production to be more moderate in mixed forests persisted when single stands with extremely high or low growth rates (e.g. those containing hybrids, shrubs or ash for instance) were excluded.

The study examined non-replicated stands at an early developmental stage, thus the findings cannot be generalized due to limitations of the experimental design discussed below. The results will have been influenced by effects of numerous uncontrolled factors, including variations in management practices, micro-site conditions, and biotic interactions (notably ash dieback). Effects of variations in management practices might explain why growth models based on empirical data for conditions in Northern Europe indicate that mixing effects on production may be weaker than the effects Pretzsch et al. $(2010,2013)$ detected for fully-stocked stands in Central Europe, where management effects were minimized. However, despite the limitations of the experimental design, data collected from the Snogeholm study site may provide important starting points for the development of future growth and management models for mixed forests, and related ecological theories. However, future studies should include experimental sites covering larger climatic gradients and a greater range of soil types (Morin et al. 2011).

Performance of Norway spruce and pedunculate oak in mixtures and monocultures

From a management perspective the production in specific forest types is more relevant than the general trend of production in mixed and pure stands. Therefore, mixing effects on Norway spruce and pedunculate oak were also examined in order to identify facilitation effects described by Pretzsch (2013). The volume growth was lower in mixtures containing Norway spruce than in monocultures of the included species, indicating that admixture had no facilitation effect (Figure 6). Regarding pedunculate oak, the growth in mixtures was higher than expected (Figure 7), indicating that the admixing had a facilitation effect on the species. However, the effects of management 
(removal of spruce in order to promote less competitive tree species) or other factors could not be separated from mixing effects due to the lack of replication.

In line with our results, Mason and Conolly (2013) found no significant differences in mean yields between Norway spruce-sessile oak mixtures and corresponding monocultures, but this may have been at least partly due to substantial variation (the relative yield ranged between $76-139 \%$ with a mean of 108\%). Interestingly, indications of negative interactions between these species during the first rotation have been detected (Brown 1992), which may have been due to poor choices of provenances (Mason and Conolly 2013). The height development of oak in mixtures with spruce at Snogeholm was also comparable to results from Scotland (Mason and Baldwin, 1995) and simulations by Linden (2003) for southern Sweden, in which oak was able to compete with spruce in height growth during the first two decades, but subsequently outcompeted without early silvicultural interventions.

\section{Statistical limitations due to the experimental design}

Under optimal conditions, working hypotheses will be the main determinants of an experiment's design. However, in this case due to the paucity of long-term experimental comparisons of mixed and pure forests on similar sites, the original experimental design was simplified, and the isolative segregation experiment (Hurlbert 1984) with 67 non-replicated treatments was treated as a randomized experiment with two treatments defined a posteriori: mixed forest and monoculture. In addition, five areas containing relatively high proportions of particular tree species were segregated (for aesthetic reasons), but the distribution of mixed stands and monocultures within these areas was randomly assigned when the experiment was established. Thus, a comparison of the defined mixed forests and monocultures on a very general level (not tree species-specifically) should provide unbiased results. With unlimited resources, a completely randomized design would be preferred, including replication (Scherer-Lorenzen et al. 2007). Due to the lack of replicates, our study does not allow multifactorial investigations (Pretzsch 2009, which would have considerably improved it, especially the possibility to distinguish mixing effects from effects of other factors. Management may have particularly affected production in spruce-oak mixtures. In addition, although the difference in removal rates between pure and mixed stands was on average small, without management some of the mixtures would have disappeared. For example, mixtures of beech with an understory of rowan, alder buckthorn, bird cherry and/or yew tend to develop rapidly towards pure beech stands.

Concerning our comparisons of mixtures including spruce and/or oak with corresponding monocultures, the use of single reference monocultures is problematic. Furthermore, the pure spruce stand consisted of a single clone (Table S2, Supplementary Information), thus the trees may have been more homogeneously sized than in typical spruce plantations.

(1) 
340 Trees in pure and mixed stands differ in size and allometric characteristics (Zingg 1994, Dieler and

341 Pretzsch 2013). However, the mean diameter of spruce and oak trees did not differ between the

342 monocultures and mixtures in our study.

343 We presume that the larger variation in their sizes in stands with relatively low proportions of these

344 species was mainly due to effects of inter-specific competition or facilitation with different tree

345 species, but also influenced by variations in site conditions, management (planting density,

346 removals), and genetic factors. However, using the mean height or diameter of spruce as indicators

347 of site conditions, no significant difference was found between the northwest and southwest parts

348 of the study area, and the sizes of oak and beech trees did not differ between the northwest and

349 northeast parts of the area. The production range of monocultures indicated in Figures 6 and 7

350 correspond to production levels expected at sites spanning one lower or higher site index class,

351 according to the growth models by Eriksson (1976) or Carbonnier (1975). Thus, we are confident that

352 production values of additional replicates of spruce and oak monocultures would have ranged within

353 this indicated interval of uncertainty.

354 It should be noted that mixing effects are unlikely to remain constant during the stands'

355 development, as growth ratios of various species change considerably over time (Bonnemann 1939,

356 Wiedemann 1943, Agestam 1985, Dittmar et al. 1986), and numerous factors influence the

357 development of mixtures (cf. Vehviläinen et al. 2007, Bolte et al. 2009, Richards et al. 2010, Lei et al.

358 2012, Hantsch et al. 2013, Forrester et al. 2014, Forrester 2014b, Pollastrini et al. 2014, Collet et al.

359 2014). In addition, Pretzsch (2013) found that some species mixtures had positive effects in older

360 stands. Thus, mixing effects in the stands at Snogeholm may shift and/or become stronger in the

361 future. Pretzsch (2013) also pointed out that better understanding of the interactions among tree

362 species is required for robust descriptions and forecasts of the development of mixed forests.

364 Conclusions for silviculture and ecosystem management

There is a greater risk of failure to establish stands when a single tree species is planted, as

366 demonstrated by the unpredictable, severe disease that specifically attacked European ash.

367 However, our results do not consistently reflect expectations of positive mixing effects on growth

368 based on niche theory (Vandermeer 1989, Scherer-Lorenzen et al. 2005). During the early

369 development stage, production of the examined stands did not generally increase with increases in

370 the number of tree species. Therefore, we reject our working hypothesis.

371 Based on the presented case-study, we can only contribute to the ongoing debate on diversity-

372 productivity relationships with the hypothesis that there is no general positive asymptotic

373 relationship between forest productivity and tree species number, as Gamfeldt et al. (2013)

374 suggested. At least, our results do not support the magnitude of the mixing effects (a $50 \%$ increase

375 in biomass production with five species compared to a single tree species) suggested by Gamfeldt et

376 al. (2013). Furthermore, the kind of tree species involved plays a key role. Other experimental

377 studies in different types of temperate and boreal forests suggest that growth differences between 
mixed and pure stands range between 0-40 \% (Mård 1996, Jonsson 2001, Jonsson 2010, Fahlvik et al. 2011, Pretzsch 2013, Mason and Conolly 2013). Our results are in line with these findings.

\section{Acknowledgements}

The study was supported by TC4F, Future Forests, Ekfrämjandet and the Southern Swedish Forest Research Centre. We thank Roland Gustavsson and Skogssällskapet, who initiated the experiment. We are grateful to Izabela Witkowska, Mateusz Liziniewicz and Dmitry Loginov, who participated in the field work and to Jan-Eric Englund and Giulia Attocchi for statistical advice. The final manuscript benefited substantially from comments by Palle Madsen and another, anonymous reviewer.

\section{References}

Agestam E. 1985. A growth simulator for mixed stands of pine, spruce and birch in Sweden. Report 15, Department of Forest Yield Research, Garpenberg, SLU (in Swedish with English summary)

Andersson S.-O. 1954. Funktioner och tabeller för kubering av småträd. Meddelanden från Statens Skogsforskningsinstitut 44:12, 29 p. [In Swedish]

Bolte A., Grundmann B., Hilbrig L., Kampf F., Brunet J. and Roloff A. 2009. Climate change impacts on stand structure and competitive interactions in a southern Swedish spruce-beech forest. European Journal of Forest Research 129, 261-276

Bonnemann A. 1939. Der gleichaltrige Mischbestand von Kiefer und Buche. Mitt. Forstwirtsch. Forstwiss. 10: 1-45 [In German]

Bosshard H.H. 1984. Holzkunde. Zur Biologie, Physik und Chemie des Holzes, Bd. 1-3, Birkhäuser, Basel. [In German]

Brown A.H.F. 1992. Functioning of mixed-species stands at Gisburn, N.W. England. In: The ecology of mixed-species stands of trees. Cannel M.G.R., Malcolm D.C., Roberston P.A. (eds) Blackwell, pp. 125150

Carbonnier C. 1954. Funktioner för kubering av europeisk, sibirisk och japansk lärk. Skogshögskolan, Institutionen för Skogsproduktion. Stockholm. 12 p. Unpublished manuscript. [In Swedish]

Carbonnier C. 1975. Produktion i kulturbestånd av ek i södra Sverige [Yield of oak plantations in southern Sweden]. Studia Forestalia Suecia 125, 89 pp. ISBN 91-38-02278-8, http://epsilon.slu.se/studia/SFS125.pdf (accessed 9 May 2012) [in Swedish with English summary]

Collet C., Ningre F., Barbeito I., Arnaud A., Piboule A. 2014. Response of tree growth and species coexistence to density and species evenness in a young forest plantation with two competing species. Annals of Botany 113: 711-719 
411 Dieler J., Pretzsch H. 2013. Morphological plasticity of European beech (Fagus sylvatica L.) in pure

412 and mixed-species stands. Forest Ecology and Management 295: 97-108

413 Dittmar O., Knapp E., Zehler H. 1986. Die langfristige Versuchsfläche Tornau im StFB Dübener Heide,

414 ein Beispiel für den Weg vom Kiefernreinbestand zum Buchennaturverjüngungsbetrieb.

415 Sozialistische Forstwirtschaft 36: 344-348 [In German]

416 Drössler L. 2010. Tree species mixtures - a common feature of southern Swedish forests. Forestry

417 83: 433-441

418 Eriksson H. 1973. Volymfunktioner för stående träd av ask, asp, klibbal och contortatall. Rapporter

419 och uppsatser $\mathrm{Nr}$ 26. Skogshögskolan, Institutionen för Skogsproduktion. Stockholm. [In Swedish]

420 Eriksson H. 1976. Granens produktion i Sverige. SLU, Institutionen för skogsproduktion, report 41 [In

421 Swedish with English summary]

422 Fahlvik N., Agestam E., Ekö P.-M., Linden M. 2011. Development of single-storied mixtures of

423 Norway spruce and birch in southern Sweden. Scandinavian Journal of Forest Research 26, 36-45

424 Felton A., Lindbladh M., Brunet J., Fritz Ö. 2010. Replacing coniferous monocultures with mixed-

425 species production stands: An assessment of the potential benefits for forest biodiversity in northern

426 Europe. Forest Ecology and Management 260, 939-947

427 Forrester D.I. 2014. The spatial and temporal dynamics of species interactions in mixed-species

428 forests: From pattern to process. Forest Ecology and Management 312: 282-292

429 Forrester D.I. 2014b. A stand-level interception model for horizontally and vertically heterogeneous

430 canopies. Ecological Modelling 276: 14-22

431 Forrester D.I., Kohnle U., Albrecht A.T., Bauhus J. 2014. Complementarity in mixed-species stands of 432 Abies alba and Picea abies varies with climate, site quality and stand density. Forest Ecology and 433 Management 304: 233-242

434 Gamfeldt L., Snäll T., Bagchi R., Jonsson M., Gustafsson L., Kjellander P., Ruiz-Jaen M.C., Fröberg M., 435 Stendahl J., Philipson C.D., Mikusiński G., Andersson E., Westerlund B., Andrén H., Moberg F., Moen 436 J., Bengtsson J. 2013. Higher levels of multiple ecosystem services are found in forests with more 437 tree species. Nature Communications 4, Article 1340, doi:10.1038/ncomms2328

438 Hagberg E., Matérn B. 1975. Volymfunktioner för stående träd av ek och bok. Materialet och dess 439 bearbetning. Rapporter och uppsatser Nr 15. Skogshögskolan, Institutionen för Skoglig Matematisk.

440 Statistik Stockholm. [In Swedish]

441 Hantsch L., Braun U., Scherer-Lorenzen M., Bruelheide H. 2013. Species richness and species identity 442 effects on occurrence of foliar fungal pathogens in a tree diversity experiment. Ecosphere 4: 81

443 Hulvey K.B., Hobbs R.J., Standish R.J., Lindenmayer D.B., Lach L., Perring M. 2013. Benefits of tree 444 mixes in carbon plantings. Nature Climate Change 3: 869-874 
Hurlbert S.H. 1984. Pseudoreplication and the design of ecological field experiments. Ecological Monographs 54: 187-211.

Isbell F., Calcagno V., Hector A., Connolly J., Harpole W.S., Reich P.B., Scherer-Lorenzen M., Schmid B., Tilman D., Ruijven J., Weigelt A., Wilsey B., Zavaleta E.S., Loreau M. 2011. High plant diversity is needed to maintain ecosystem services. Nature 477: 199-203

Jonsson B. 2001. Volume yield to mid-rotation in pure and mixed sown stands of Pinus sylvestris and Picea abies in Sweden. Studia Forestalia Suecica 211. ISSN 91-576-6137-5 Jonsson B. 2010. Dynamics of field-layer vegetation and tree growth in young Pinus sylvestris and Picea abies stands on microsites in Swedish Lapland. Skog \& Trä 2010:5. SLU, Unit for Field-based Forest research, Vindeln Experimental forest. ISBN 978-91-977896-6-0

Kelty, M.J. 1992. Comparative productivity of monocultures and mixed-species stands. In: The ecology and silviculture of mixed-species forests. M.J. Kelty, B.C. Larson and C.D. Oliver (eds). Kluwer, Dordrecht, The Netherlands. pp. 125-141

Knigge W., Schulz H. 1966. Grundriss der Forstbenutzung. Parey, Hamburg. p. 584. [In German]

Lei P., Scherer-Lorenzen M., Bauhus J. 2012. The effect of tree species diversity on fine-root production in a young temperate forest. Oecologia 169: 1105-1115

Linden M. 2003. Increment and yield in mixed stands with Norway spruce in southern Sweden. Doctoral dissertation. Acta Universitatis Agrigulturae Sueciae, Silvestria 260

Loginov D. 2012. Oak in mixtures and monocultures - results from the Snogeholm study area in southern Sweden. SLU, M.Sc. Thesis no. 185, Southern Swedish Forest Research Centre, Alnarp. http://stud.epsilon.slu.se/3971/1/Loginov_D_120314.pdf (accessed 13 June 2013) Mård H, 1996, The influence of a birch shelter (Betula spp) on the growth of young stands of Picea abies. Scandinavian Journal of Forest Research 11, 343-350

Mason B., Baldwin E. 1995. Performance of pedunculate oak after 40 years in mixture with European Larch and Norway spruce in southern Scotland. Scottish Forestry 49, 5-13

Mason W., Connolly T. 2013. The development of species mixtures in British spruce forests: guidance from the Gisburn experiment. Forestry 0, 1-9, doi:10.1093/forestry/cpt042

Mielikäinen K. 1985. Effect of an admixture of birch on the structure and development of Norway spruce stands. Communicationes Instituti Forestalis Fenniae. 99: 1-82 (in Finnish with English summary)

Morin X., Fahse L., Scherer-Lorenzen M., Bugmann H. 2011. Tree species richness promotes productivity in temperate forests through strong complementarity between species. Ecology Letters $14,1211-1219$ 
Näslund M. 1947. Funktioner och tabeller för kubering av stående träd . Tall, gran och björk i södra Sverige samt i hela landet. Meddelande från Statens skogsforskningsinstitut Band 36:3. Stockholm. [In Swedish]

Nielsen N.-E. 1996. The forests. National atlas of Sweden. Stockholm, SNA förlag. ISBN 91-87760-061

Nielsen A.B. 2011. Landscape laboratories 2008-10 - Guided and supervised activities \& publications. SLU, Faculty of Landscape Planning, Horticulture and Agricultural Science, working report 2011:21, ISBN 978-91-86373-72-6

Petterson N. 1992. The effect on stand development of different spacing after planting and precommercial thinning in Norway spruce (Picea abies (L.) Karst.) and Scots pine (Pinus silvestris L.) stands. PhD thesis. SLU, Department of Forest Yield Research, Report 34, ISSN 03487636

Pollastrini M., Holland V, Bruggemann W., Koricheva J., Jussila I., Scherer-Lorenzen M., Berger S., Bussotti F. 2014. Interactions and competition processes among tree species in young experimental mixed forests, assessed with chlorophyll fluorescence and leaf morphology. Plant Biology 16: 323331.

Pretzsch H. 2009. Forest dynamics, growth and yield. From measurement to model, Springer, Berlin, Heidelberg, $664 \mathrm{p}$.

Pretzsch H., Block J., Dieler J., Dong P.H., Kohnle U., Nagel J., Spellmann H., Zingg A. 2010.

Comparison between the productivity of pure and mixed stands of Norway spruce and European beech along an ecological gradient. Annals of Forest Science 67, 712

Pretzsch H. 2013. Facilitation and competition in mixed-species forests analyzed along an ecological gradient. Nova Acta Leopoldina NF 114, Nr. 391: 159-174

Pretzsch H., Bielak K., Block J., Bruchwald A., Dieler J., Ehrhart H.P., Kohnle U., Nagel J., Spellmann H., Zasada M., Zingg A. 2013. Productivity of mixed versus pure stands of oak (Quercus petraea (Matt.) Liebl. and Quercus robur L.) and European beech (Fagus sylvatica L.) along an ecological gradient. European Journal of Forest Research DOI 10.1007/s10342-012-0673-y

Richards, A.E., Forrester, D.I., Bauhus, J., Scherer-Lorenzen M. 2010. The influence of mixed tree plantations on the nutrition of individual species: a review. Tree Physiology 30, 1192-1208

Rio M., Sterba H. 2009. Comparing volume growth in pure and mixed stands of Pinus silvestris and Quercus pyrenaica. Annals of Forest Science 66: 502

Saha S., Kuehne C., Kohnle U., Brang P., Ehring A., Geisl J., Leder B., Muth M., Petersen R., Peter J., Ruhm W., Bauhus J. 2012. Growth and quality of young oaks (Quercus robur and Quercus petraea) grown in cluster plantings in central Europe: A weighted meta-analysis. Forest Ecology and Management 283:106-118

Scherer-Lorenzen M., Körner C., Schulze E. D. 2005. Forest Diversity and Function. Vol. 176. Springer, Heidelberg, Berlin 
516 Scherer-Lorenzen M., Schulze E.-D., Don A., Schumacher J., Weller, E. 2007. Exploring the functional

517 significance of forest diversity: A new long-term experiment with temperate tree species (BIOTREE).

518 Perspectives in Plant Ecology, Evolution and Systematics 9:53-70

519 SMHI 2009. Normal uppskattad årsnederbörd, medelvärde 1961-1990. SMHI, Norrköping.

520 http://www.smhi.se/klimatdata/meteorologi/nederbord/1.6934 (accessed 20 June 2013). [In

521 Swedish]

522 Vandermeer J. 1989. The ecology of intercropping. Cambridge University press. Cambridge

523 Vehviläinen H., Koricheva J., Ruohomäki K. 2007. Tree species diversity influences herbivore

524 abundance and damage: meta-analysis of long-term forest experiments. Oecologia 152: 287-298

525 Vilà M., Carrillo-Gavilán A., Vayreda J., Bugmann H., Fridman J., Grodzki W., Haase J., Kunstler G.,

526 Schelhaas M., Trasobares A. 2013. Disentangling biodiversity and climatic determinants of wood

527 production. PLoS ONE 8, e53530.

528 Wagenführ R. 2007. Holzatlas. 6th edition. Fachbuchverlag, Leipzig. ISBN 978-3-446-40649-0. [In

529 German.]

530 Wiedemann E. 1943. Der Vergleich der Massenleistung des Mischbestandes mit dem Reinbestand.

531 AFJZ 119: 123-132 [In German]

Zingg A. 1994. Top heights in mixed stands: their definition and calculation. In: Pinto da Costa M.E.,

533 Preuhsler T. (eds) Mixed stands. Research plots, measurements and results, models. Proceedings

534 from the Symposium of the IUFRO working groups S4.01-03: Design, performance and evaluation of 535 experiments, and S4.01-04: Growth models for tree and stand simulation. April 25-29, 1994 in

536 Lousa/Coimbra, Portugal. Lisboa, Instituto Superior Agronomia, Universidade de Lisboa. 67-79.

537

538

539

540

541

542

543

544

545

546

547 


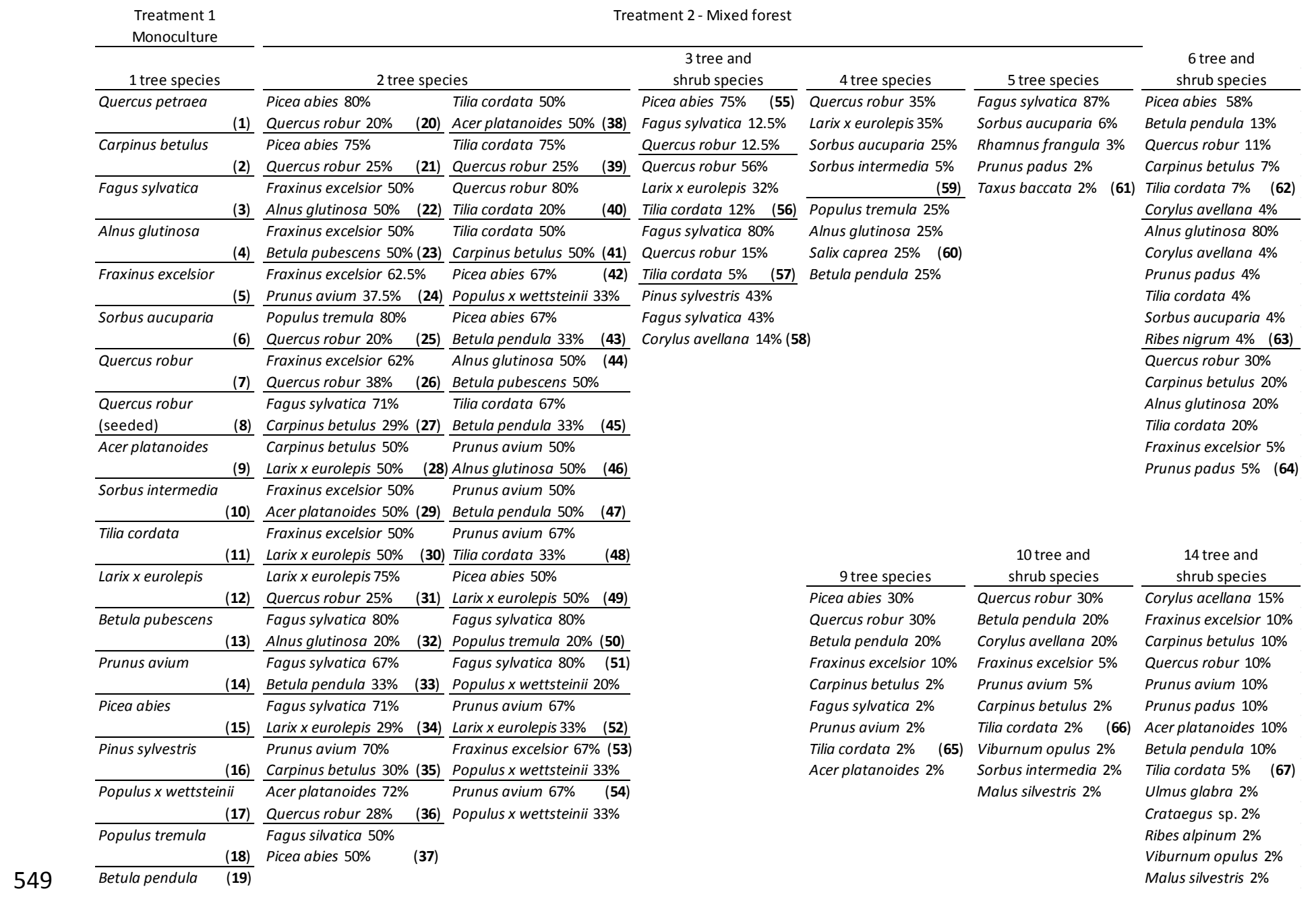


Table 2. Volume functions used in this study

\begin{tabular}{lll}
\hline Species & Reference & Tree size \\
\hline Pinus sylvestris & Andersson 1954 & $<5 \mathrm{~cm} \mathrm{dbh}$ \\
Pinus sylvestris & Näslund 1947 & $\geq 5 \mathrm{~cm} \mathrm{dbh}$ \\
Picea abies & Andersson 1954 & $<5 \mathrm{~cm} \mathrm{dbh}$ \\
Picea abies & Näslund 1947 & $\geq 5 \mathrm{~cm} \mathrm{dbh}$ \\
Betula sp. & Andersson 1954 & $<5 \mathrm{~cm} \mathrm{dbh}$ \\
Betula sp. & Näslund 1947 & $\geq 5 \mathrm{~cm} \mathrm{dbh}$ \\
Fraxinus excelsior & Eriksson 1973 & \\
Populus sp. & Eriksson 1973 & \\
Larix sp. & Carbonnier 1954 \\
Oak, beech, others & Hagberg and Matérn 1975 \\
\hline
\end{tabular}

562

563

564

565

566

567

568

569

570

571

572

573

574

575

576

577

578

579

580 
581 Table 4. Specific wood densities of tree species $\left(500 \mathrm{~kg} / \mathrm{m}^{3}\right.$ was assumed for other tree and shrub 582 species accounting for less than $5 \%$ of a mixture)

\begin{tabular}{lcl} 
Tree species & $\begin{array}{c}\text { Wood density } \\
\left(\mathrm{kg} / \mathrm{m}^{3}\right)\end{array}$ & Reference \\
\hline Oak & 640 & Knigge and Schulz, 1966 \\
Hornbeam & 780 & Wagenführ, 2007 \\
Beech & 660 & Knigge and Schulz, 1966 \\
Alder & 510 & Wagenführ, 2007 \\
Ash & 650 & Knigge and Schulz, 1966 \\
Maple & 590 & Knigge and Schulz, 1966 \\
Lime & 490 & Bosshard, 1984 \\
Birch & 610 & Bosshard, 1984 \\
Cherry & 550 & Wagenführ, 2007 \\
Elm & 640 & Knigge and Schulz, 1966 \\
Larch & 550 & Knigge and Schulz, 1966 \\
Spruce & 430 & Knigge and Schulz, 1966 \\
Pine & 490 & Knigge and Schulz, 1966 \\
Poplar & 370 & Knigge and Schulz, 1966 \\
Sorbus spec. & 710 & Wagenführ, 2007 \\
Hazel & 550 & Wagenführ, 2007 \\
Bird cherry & 610 & Wagenführ, 2007 \\
Willow & 430 & Bosshard, 1984
\end{tabular}


5

6

7

8

9

10

11

12

13

14

15

16

17

18

19

20

21

22

23

24

25

26

27
SUPPLEMENT

to the manuscript

Early development of pure and mixed tree species plantations in Snogeholm, southern Sweden submitted to the Scandinavian Journal of Forest Research

*Corresponding author: Lars.drossler@slu.se 
28 Table S1. Total production of standing volume and dry wood biomass on each study plot at

29 Snogeholm during the first 15 years after establishment, with and without correction for variations

30 in the initial plant density and production, according to Petterson (1992).

\begin{tabular}{|c|c|c|c|c|c|c|}
\hline 1 tree species & $\begin{array}{c}\text { Initial planting } \\
\text { density (trees/ha) }\end{array}$ & $\begin{array}{c}\text { Total volume } \\
\text { production }\left(\mathrm{m}^{3} \mathrm{ha}^{-1}\right)\end{array}$ & $\begin{array}{l}\text { Density-corrected } \\
\text { total volume } \\
\text { production }\left(\mathrm{m}^{3} \mathrm{ha}^{-1}\right)\end{array}$ & $\begin{array}{c}\text { Total biomass } \\
\text { production }\left(\mathrm{t} \mathrm{ha}^{-1}\right)\end{array}$ & $\begin{array}{c}\text { Mean } \\
\text { height }(m)\end{array}$ & $\begin{array}{c}\text { Mean } \\
\text { diameter }(\mathrm{cm}) \\
\end{array}$ \\
\hline Quercus petraea & 6000 & 85 & 73 & 54.4 & 8.0 & 6.7 \\
\hline Carpinus betulus & 4000 & 59 & 57 & 46.0 & 8.2 & 5.8 \\
\hline Fagus sylvatica & 6000 & 48 & 41 & 31.7 & 7.1 & 5.7 \\
\hline Alnus glutinosa & 2600 & 129 & 147 & 65.8 & 11.6 & 12.3 \\
\hline Fraxinus excelsior & 2600 & 9 & 10 & 5.9 & 3.9 & 5.5 \\
\hline Sorbus aucuparia & 3000 & 24 & 26 & 12.0 & 5.7 & 5.2 \\
\hline Quercus robur & 6000 & 87 & 75 & 55.7 & 8.7 & 7.1 \\
\hline Quercus robur (seeded) & 10000 seeds/ha & $<1$ & $<1$ & $<1$ & - & - \\
\hline Acer platanoides & 2600 & 23 & 26 & 13.6 & 6.2 & 5.3 \\
\hline Sorbus intermedia & 3000 & 39 & 42 & 27.7 & 5.9 & 6.6 \\
\hline Tilia cordata & 3200 & 136 & 142 & 66.6 & 8.8 & 8.1 \\
\hline Larix $x$ eurolepis & 2400 & 253 & 298 & 139.2 & 14.2 & 16.4 \\
\hline Betula pubescens & 2500 & 113 & 131 & 68.9 & 11.8 & 9.9 \\
\hline Prunus avium & 2800 & 32 & 35 & 17.6 & 6.6 & 5.3 \\
\hline Picea abies & 3000 & 209 & 224 & 89.9 & 11.9 & 11.6 \\
\hline Pinus sylvestris & 6800 & 245 & 204 & 107.8 & 9.3 & 9.8 \\
\hline Populus $x$ wettsteinii & 1600 & 279 & 404 & 103.2 & 19.9 & 18.4 \\
\hline Populus tremula & 2400 & 92 & 108 & 34.0 & 11.2 & 10.2 \\
\hline Betula pendula & 2400 & 145 & 171 & 88.5 & 14.1 & 13.3 \\
\hline \multicolumn{7}{|l|}{$\mathbf{2}$ tree species } \\
\hline Picea abies $80 \%$ & \multirow{2}{*}{4000} & \multirow{2}{*}{182} & \multirow{2}{*}{175} & \multirow{2}{*}{79.9} & 11.0 & 5.8 \\
\hline Quercus robur $20 \%$ & & & & & 7.2 & 13.7 \\
\hline Picea abies $75 \%$ & \multirow{2}{*}{4000} & \multirow{2}{*}{118} & \multirow{2}{*}{114} & \multirow{2}{*}{52.2} & 9 & 5.4 \\
\hline Quercus robur $25 \%$ & & & & & 6.6 & 10.3 \\
\hline Fraxinus excelsior $50 \%$ & \multirow{2}{*}{2520} & \multirow{2}{*}{70} & \multirow{2}{*}{81} & \multirow{2}{*}{37.4} & 7.8 & 6.6 \\
\hline Alnus glutinosa $50 \%$ & & & & & 9.1 & 11.3 \\
\hline Fraxinus excelsior $50 \%$ & \multirow{2}{*}{2520} & \multirow{2}{*}{49} & \multirow{2}{*}{57} & \multirow{2}{*}{30.4} & 7.1 & 6.2 \\
\hline Betula pubescens $50 \%$ & & & & & 9.7 & 9.3 \\
\hline Fraxinus excelsior $62.5 \%$ & \multirow{2}{*}{3200} & \multirow{2}{*}{11} & \multirow{2}{*}{11} & \multirow{2}{*}{6.1} & 4.7 & 3.4 \\
\hline Prunus avium $37.5 \%$ & & & & & 6.1 & 6.1 \\
\hline Populus tremula $80 \%$ & \multirow{2}{*}{4000} & \multirow{2}{*}{85} & \multirow{2}{*}{82} & \multirow{2}{*}{38.5} & 10.7 & 8.1 \\
\hline Quercus robur $20 \%$ & & & & & 8.7 & 9.8 \\
\hline Fraxinus excelsior $62 \%$ & \multirow{2}{*}{3200} & 40 & 42 & 257 & 4.7 & 4.4 \\
\hline Quercus robur $38 \%$ & & 40 & 42 & 25.1 & 7.9 & 9.4 \\
\hline Fagus sylvatica $71 \%$ & 5600 & 51 & 44 & 365 & 6.6 & 5.2 \\
\hline Carpinus betulus $29 \%$ & 5000 & 31 & 44 & 36.5 & 7.0 & 5.3 \\
\hline Carpinus betulus $50 \%$ & 3175 & 166 & 174 & 987 & 8.4 & 7.0 \\
\hline Larix $x$ eurolepis $50 \%$ & $31 / 5$ & 106 & $1 / 4$ & 98.2 & 13.5 & 20.0 \\
\hline
\end{tabular}




\begin{tabular}{|c|c|c|c|c|c|c|}
\hline 2 tree species & $\begin{array}{c}\text { Initial planting } \\
\text { density (trees/ha) }\end{array}$ & $\begin{array}{c}\text { Total volume } \\
\text { production }\left(\mathrm{m}^{3} \mathrm{ha}^{-1}\right)\end{array}$ & $\begin{array}{c}\text { total volume } \\
\text { production }\left(\mathrm{m}^{3} \mathrm{ha}^{-1}\right)\end{array}$ & $\begin{array}{c}\text { Total biomass } \\
\text { production }\left(\mathrm{t} \mathrm{ha}^{-1}\right)\end{array}$ & $\begin{array}{c}\text { Mean } \\
\text { height }(\mathrm{m})\end{array}$ & $\begin{array}{c}\text { Mean } \\
\text { diameter }(\mathrm{cm}) \\
\end{array}$ \\
\hline Fraxinus excelsior $50 \%$ & \multirow{2}{*}{2520} & \multirow{2}{*}{18} & \multirow{2}{*}{21} & \multirow{2}{*}{10.9} & 6.6 & 6.1 \\
\hline Acer platanoides $50 \%$ & & & & & 6.5 & 6.3 \\
\hline Fraxinus excelsior $50 \%$ & \multirow{2}{*}{2520} & \multirow{2}{*}{165} & \multirow{2}{*}{190} & \multirow{2}{*}{93.7} & - & - \\
\hline Larix $x$ eurolepis $50 \%$ & & & & & 13.3 & 17.7 \\
\hline Larix $x$ eurolepis $75 \%$ & \multirow{2}{*}{3200} & \multirow{2}{*}{182} & \multirow{2}{*}{190} & \multirow{2}{*}{101.2} & 13.4 & 16.0 \\
\hline Quercus robur $25 \%$ & & & & & 8.4 & 7.3 \\
\hline Fagus sylvatica $80 \%$ & \multirow{2}{*}{5000} & \multirow{2}{*}{126} & \multirow{2}{*}{113} & \multirow{2}{*}{73.7} & 8.3 & 7.2 \\
\hline Alnus glutinosa $20 \%$ & & & & & 10.7 & 14.2 \\
\hline Fagus sy/vatica $67 \%$ & \multirow{2}{*}{5000} & \multirow{2}{*}{96} & \multirow{2}{*}{86} & 59.6 & 6.9 & 5.3 \\
\hline Betula pendula $33 \%$ & & & & 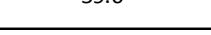 & 12.9 & 15.0 \\
\hline Fagus sylvatica $71 \%$ & 4667 & 122 & 112 & 69.9 & 6.5 & 5.7 \\
\hline Larix $x$ eurolepis $29 \%$ & 年 & 12L & Ar & 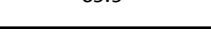 & 12.6 & 19.7 \\
\hline Prunus avium $70 \%$ & 2800 & 100 & 110 & 58.2 & 10.1 & 8.4 \\
\hline Carpinus betulus $30 \%$ & 2000 & 100 & 110 & 50.2 & 8.3 & 5.7 \\
\hline Acer platanoides $72 \%$ & 3600 & 68 & 68 & 40.9 & 8.5 & 5.9 \\
\hline Quercus robur $28 \%$ & 5000 & 00 & 00 & 40.9 & 7.9 & 7.5 \\
\hline Fagus silvatica $50 \%$ & 4000 & 144 & 139 & 66.3 & 7.1 & 6.0 \\
\hline Picea abies $50 \%$ & 4000 & 144 & 139 & 00.3 & 10.4 & 13.6 \\
\hline Tilia cordata $50 \%$ & 2520 & 103 & 119 & 56 & 9.0 & 7.6 \\
\hline Acer platanoides $50 \%$ & $\angle \supset \angle U$ & 105 & 119 & 50 & 10.2 & 8.1 \\
\hline Tilia cordata $75 \%$ & 3200 & 113 & 118 & 57.9 & 7.7 & 7.1 \\
\hline Quercus robur $25 \%$ & $3<00$ & 113 & 118 & 31.9 & 7.7 & 8.6 \\
\hline Quercus robur $80 \%$ & 5000 & 75 & 67 & 423 & 7.5 & 5.9 \\
\hline Tilia cordata $20 \%$ & 000 & 10 & 年 & Th. & 6.9 & 6.3 \\
\hline Tilia cordata $50 \%$ & 4000 & 120 & 116 & 73.9 & 8.3 & 7.3 \\
\hline Carpinus betulus $50 \%$ & 4000 & $1 \angle U$ & 110 & 13.9 & 8.8 & 8.6 \\
\hline Picea abies $67 \%$ & 2400 & 280 & 330 & 1091 & 10.1 & 11.7 \\
\hline Populus $x$ wettsteinii $33 \%$ & 2400 & 280 & 330 & 109.1 & 20.4 & 22.5 \\
\hline Picea abies $67 \%$ & 3000 & 187 & 200 & 99.0 & 10.1 & 10.9 \\
\hline Betula pendula $33 \%$ & & & & (5.0.0 & 14.2 & 15.1 \\
\hline Alnus glutinosa $50 \%$ & 2600 & 140 & 159 & 77.0 & 12.4 & 13.7 \\
\hline Betula pubescens $50 \%$ & & & & & 12.6 & 10.4 \\
\hline Tilia cordata $67 \%$ & 3000 & 133 & 143 & 735 & 8.6 & 6.7 \\
\hline Betula pendula $33 \%$ & 000 & كנד & $1+3$ & 10.5 & 14.4 & 15.8 \\
\hline Prunus avium 50\% & 2520 & 92 & 106 & 58.8 & 9.6 & 11.5 \\
\hline Alnus glutinosa $50 \%$ & 200 & रू & 100 & 30.0 & 9.4 & 10.1 \\
\hline Prunus avium 50\% & 2520 & 146 & 168 & 85.2 & 12.8 & 15.0 \\
\hline Betula pendula $50 \%$ & $20<0$ & 140 & 100 & 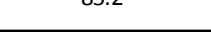 & 16.3 & 15.1 \\
\hline Prunus avium 67\% & 3000 & 89 & 95 & 47.4 & 8.4 & 6.9 \\
\hline Tilia cordata $33 \%$ & & & & & 7.2 & 6.7 \\
\hline Picea abies $50 \%$ & 2800 & 256 & 282 & 1172 & 10.9 & 10.3 \\
\hline Larix $x$ eurolepis $50 \%$ & 2000 & 200 & 202 & 111.2 & 14.6 & 21.0 \\
\hline Fagus sylvatica $80 \%$ & 4000 & 127 & 122 & $59 ?$ & 8.4 & 6.0 \\
\hline Populus tremula $20 \%$ & 4000 & 121 & 122 & (5.2 & 12.3 & 13.2 \\
\hline Fagus sy/vatica $80 \%$ & 4000 & 178 & 172 & 72.5 & 7.1 & 5.6 \\
\hline Populus $x$ wettsteinii $20 \%$ & & & & & 20.0 & 30.9 \\
\hline Prunus avium 67\% & 3000 & 151 & 162 & 57.8 & 10.6 & 8.5 \\
\hline Larix $x$ eurolepis $33 \%$ & & & & & 14.5 & 15.4 \\
\hline Fraxinus excelsior $67 \%$ & 2800 & 158 & 174 & 61 & 8.0 & 5.2 \\
\hline Populus $x$ wettsteinii $33 \%$ & & & & & 18.2 & 15.2 \\
\hline Prunus avium 67\% & 2800 & 146 & 161 & 64.1 & 10.4 & 8.6 \\
\hline Populus x wettsteinii 33\% & 2800 & 140 & 101 & 04.1 & 19.0 & 31.0 \\
\hline
\end{tabular}




\begin{tabular}{|c|c|c|c|c|c|c|}
\hline 3 tree and shrub species & $\begin{array}{c}\text { Initial planting } \\
\text { density (trees/ha) }\end{array}$ & $\begin{array}{c}\text { Total volume } \\
\text { production }\left(\mathrm{m}^{3} \mathrm{ha}^{-1}\right)\end{array}$ & $\begin{array}{l}\text { Density-corrected } \\
\text { total volume } \\
\text { production }\left(\mathrm{m}^{3} \mathrm{ha}^{-1}\right)\end{array}$ & $\begin{array}{c}\text { Total biomass } \\
\text { production }\left(\mathrm{t} \mathrm{ha}^{-1}\right)\end{array}$ & $\begin{array}{c}\text { Mean } \\
\text { height }(m)\end{array}$ & $\begin{array}{c}\text { Mean } \\
\text { diameter }(\mathrm{cm}) \\
\end{array}$ \\
\hline Picea abies $75 \%$ & & & & & 9.9 & 11.5 \\
\hline Fagus sylvatica $12.5 \%$ & 4000 & 153 & 148 & 67.3 & 5.1 & 4.5 \\
\hline Quercus robur $12.5 \%$ & & & & & 6.8 & 5.9 \\
\hline Quercus robur 56\% & & & & & 8.1 & 6.4 \\
\hline Larix $x$ eurolepis $32 \%$ & 3600 & 134 & 134 & 74.4 & 11.6 & 16.7 \\
\hline Tilia cordata $12 \%$ & & & & & 8.2 & 9.2 \\
\hline Fagus sylvatica $80 \%$ & & & & & 7.3 & 7.3 \\
\hline Quercus robur $15 \%$ & 5000 & 67 & 60 & 43.6 & 7.5 & 8.1 \\
\hline Tilia cordata $5 \%$ & & & & & 7.1 & 9.1 \\
\hline Pinus sylvestris $43 \%$ & & & & & 8.8 & 12.4 \\
\hline Fagus sylvatica $43 \%$ & 5600 & 95 & 83 & 50.5 & 8.0 & 6.8 \\
\hline Corylus avellana $14 \%$ & & & & & - & - \\
\hline
\end{tabular}

4 tree species

\begin{tabular}{|c|c|c|c|c|c|c|}
\hline Quercus robur 35\% & \multirow{4}{*}{3200} & \multirow{4}{*}{145} & \multirow{4}{*}{151} & \multirow{4}{*}{80.9} & 8.6 & 7.9 \\
\hline Larix x eurolepis 35\% & & & & & 13.5 & 19.2 \\
\hline Sorbus aucuparia $25 \%$ & & & & & 6.9 & 5.0 \\
\hline Sorbus intermedia $5 \%$ & & & & & 6.6 & 5.4 \\
\hline Populus tremula $25 \%$ & \multirow{4}{*}{3000} & \multirow{4}{*}{150} & \multirow{4}{*}{161} & \multirow{4}{*}{50.7} & 12.6 & 10.7 \\
\hline Alnus glutinosa $25 \%$ & & & & & 10.9 & 8.1 \\
\hline Salix caprea $25 \%$ & & & & & 9.6 & 7.2 \\
\hline Betula pendula $25 \%$ & & & & & 14.6 & 15.1 \\
\hline \multicolumn{7}{|l|}{5 tree species } \\
\hline Fagus sylvatica $87 \%$ & & & & & 7.1 & 5.6 \\
\hline Sorbus aucuparia $6 \%$ & & & & & 6.1 & 3.9 \\
\hline Rhamnus frangula $3 \%$ & 6400 & 63 & 53 & 41.1 & 6.5 & 5.0 \\
\hline Prunus padus $2 \%$ & & & & & - & - \\
\hline Taxus baccata $2 \%$ & & & & & - & - \\
\hline
\end{tabular}

6 tree and shrub species

\begin{tabular}{|c|c|c|c|c|c|c|}
\hline Picea abies $58 \%$ & & \multirow{6}{*}{126} & \multirow{6}{*}{117} & \multirow{6}{*}{60.8} & 9.6 & 10.1 \\
\hline Betula pendula $13 \%$ & \multirow{5}{*}{4444} & & & & 11.5 & 11.0 \\
\hline Quercus robur $11 \%$ & & & & & 7.0 & 5.7 \\
\hline Carpinus betulus $7 \%$ & & & & & 6.8 & 4.5 \\
\hline Tilia cordata $7 \%$ & & & & & 5.7 & 4.5 \\
\hline Corylus avellana $4 \%$ & & & & & - & - \\
\hline Alnus glutinosa $80 \%$ & \multirow{6}{*}{3100} & \multirow{6}{*}{136} & \multirow{6}{*}{144} & \multirow{6}{*}{69.2} & 11.5 & 12.2 \\
\hline Corylus avellana $4 \%$ & & & & & - & - \\
\hline Prunus padus $4 \%$ & & & & & 9.1 & 8.1 \\
\hline Tilia cordata $4 \%$ & & & & & 8.4 & 9.2 \\
\hline Sorbus aucuparia $4 \%$ & & & & & 5.7 & 4.7 \\
\hline Ribes nigrum 4\% & & & & & - & - \\
\hline Quercus robur 30\% & \multirow{6}{*}{4444} & \multirow{6}{*}{104} & \multirow{6}{*}{97} & \multirow{6}{*}{59.1} & 7.7 & 7.4 \\
\hline Carpinus betulus $20 \%$ & & & & & 7.0 & 6.6 \\
\hline Alnus glutinosa $20 \%$ & & & & & 7.7 & 9.4 \\
\hline Tilia cordata $20 \%$ & & & & & 7.6 & 7.1 \\
\hline Fraxinus excelsior $5 \%$ & & & & & 6.5 & 6.0 \\
\hline Prunus padus $5 \%$ & & & & & 6.6 & 6.2 \\
\hline
\end{tabular}


Table S1 - continued.

\begin{tabular}{|c|c|c|c|c|c|c|}
\hline 9 tree species & $\begin{array}{c}\text { Initial planting } \\
\text { density (trees/ha) }\end{array}$ & $\begin{array}{c}\text { Total volume } \\
\text { production }\left(\mathrm{m}^{3} \mathrm{ha}^{-1}\right)\end{array}$ & $\begin{array}{l}\text { Density-corrected } \\
\text { total volume } \\
\text { production }\left(\mathrm{m}^{3} \mathrm{ha}^{-1}\right)\end{array}$ & $\begin{array}{c}\text { Total biomass } \\
\text { production }\left(\mathrm{t} \mathrm{ha}^{-1}\right)\end{array}$ & $\begin{array}{c}\text { Mean } \\
\text { height }(\mathrm{m})\end{array}$ & $\begin{array}{c}\text { Mean } \\
\text { diameter }(\mathrm{cm}) \\
\end{array}$ \\
\hline Picea abies $30 \%$ & & & & & 10.5 & 13.7 \\
\hline Quercus robur $30 \%$ & & & & & 7.2 & 5.9 \\
\hline Betula pendula $20 \%$ & & & & & 12.2 & 13.2 \\
\hline Fraxinus excelsior $10 \%$ & & & & & 6.6 & 5.0 \\
\hline Carpinus betulus $2 \%$ & 4444 & 112 & 104 & 55.9 & 8.4 & 7.8 \\
\hline Fagus sylvatica $2 \%$ & & & & & 6.2 & 6.2 \\
\hline Prunus avium $2 \%$ & & & & & 6.4 & 6.1 \\
\hline Tilia cordata $2 \%$ & & & & & 6.4 & 6.5 \\
\hline Acer platanoides $2 \%$ & & & & & 6.5 & 4.1 \\
\hline
\end{tabular}

10 tree and shrub species

\begin{tabular}{|c|c|c|c|c|c|c|}
\hline Quercus robur $30 \%$ & \multirow{10}{*}{4440} & \multirow{10}{*}{79} & \multirow{10}{*}{74} & \multirow{10}{*}{48.2} & 7.6 & 6.9 \\
\hline Betula pendula $20 \%$ & & & & & 12.2 & 12.2 \\
\hline Corylus avellana $20 \%$ & & & & & - & - \\
\hline Fraxinus excelsior $5 \%$ & & & & & 5.9 & 4.6 \\
\hline Prunus avium $5 \%$ & & & & & 8.1 & 8.9 \\
\hline Carpinus betulus $2 \%$ & & & & & 7.4 & 6.3 \\
\hline Tilia cordata $2 \%$ & & & & & 6.5 & 8.6 \\
\hline Viburnum opulus $2 \%$ & & & & & - & - \\
\hline Sorbus intermedia $2 \%$ & & & & & 6.2 & 5.5 \\
\hline Malus silvestris $2 \%$ & & & & & 6.2 & 4.5 \\
\hline
\end{tabular}

Malus silvestris 2\%

14 tree and shrub species

Corylus acellana $15 \%$

Fraxinus excelsior 10\%

Carpinus betulus 10\%

Quercus robur $10 \%$

Prunus avium $10 \%$

Prunus padus $10 \%$

Acer platanoides $10 \%$

Betula pendula $10 \%$

97

90

61.0

$8.2 \quad 6.8$

Tilia cordata 5\%

Ulmus glabra $2 \%$

Crataegus spec. $2 \%$

Ribes alpinum 2\%

Viburnum opulus $2 \%$ 
Table S2. Types of planting stock and seed sources (age is distinguished in years before/after

67 transplantation in the nursery).

\begin{tabular}{l|c|c|l} 
Tree species & Age (years) & Size (cm) & Provenance (country) \\
\hline Quercus robur & $1 / 0$ & $15-30$ & Blekinge (SE) \\
Quercus petraea & $2 / 0$ & $30-50$ & Agder (NOR) \\
Betula pendula & $1 / 0$ & $50+$ & Asarum (SE) \\
Betula pubescens & $1 / 1$ & $40-60$ & Lassjön (SE) \\
Picea abies & $1.5 / 1.5$ & - & Maglehem (SE) \\
Alnus glutinosa & $1 / 0,1 / 1$ & $20-40,40+$ & Ignaberga (SE) \\
Larix x eurolepis & $1 / 1$ & - & Maglehem (SE) \\
Acer platanoides & - & $40-60$ & North Germany \\
Populus x wettsteinii & $0 / 1$ & - & Götaland (SE) \\
Fraxinus excelsior & $2 / 0$ & $25-30$ & Uppland (SE) \\
Carpinus betulus & $1 / 2$ & $50-80$ & Scania (SE) \\
Prunus avium & $1 / 0$ & $50-80$ & Skaraborg (SE) \\
Sorbus intermedia & $1 / 1$ & $30-50$ & Uppland (SE) \\
Sorbus aucuparia & $1 / 1$ & $50-80$ & Uppland (SE) \\
Fagus sylvatica & $1 / 2$ & - & Ransåsa (SE)
\end{tabular}



growth and height growth of a given tree species in mixtures and monoculture.

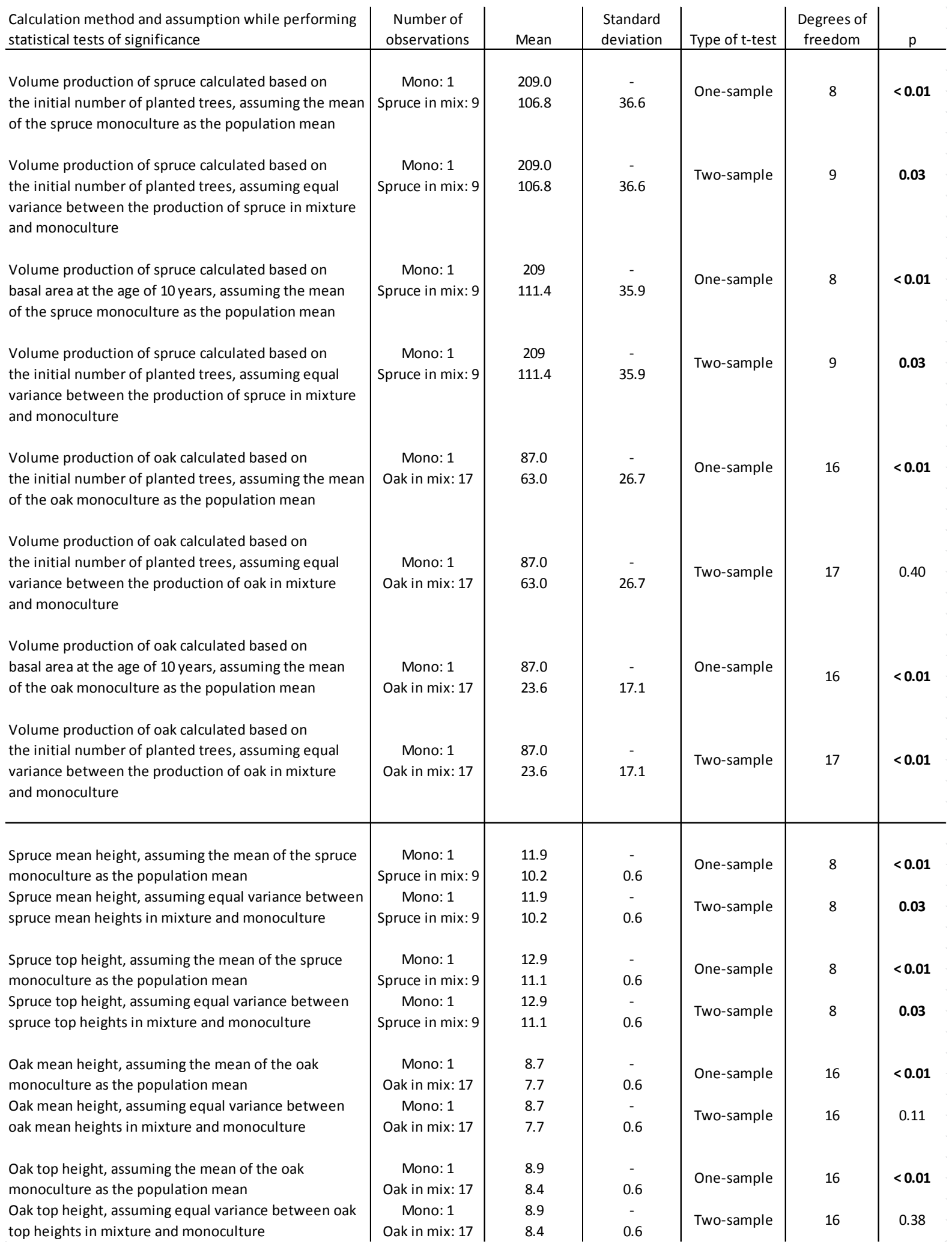


88 Table S4. Comparison of volume production of climax/intermediate tree species i (beech, oak, 89 spruce, lime, hornbeam) with admixture of a pioneer/nurse tree species ip (alder, birch, poplar, 90 larch, shrubs) - with proportions of tree species estimated in indicated manners.

\begin{tabular}{|c|c|c|c|c|c|c|}
\hline Grouping without and with monocultures & $\begin{array}{c}\text { Number of } \\
\text { observations }\end{array}$ & Mean & $\begin{array}{l}\text { Standard } \\
\text { deviation }\end{array}$ & Type of t-test & $\begin{array}{c}\text { Degrees of } \\
\text { freedom }\end{array}$ & $\mathrm{p}$ \\
\hline $\begin{array}{l}\text { Climax/intermediate tree species mixtures }(i) \text { versus } \\
\text { mixtures of one or two of these species with a pioneer/ } \\
\text { nurse tree species }(p)^{*}\end{array}$ & $\begin{array}{l}\text { i mix: } 9 \\
\text { ip mix: } 13\end{array}$ & $\begin{array}{l}121.7 \\
138.2\end{array}$ & $\begin{array}{l}50.4 \\
62.2\end{array}$ & Two-sample & 21 & 0.50 \\
\hline $\begin{array}{l}\text { Climax/intermediate tree species (pure and mixed) } \\
\text { versus mixtures of one or two of these species } \\
\text { with a pioneer/nurse tree species* }\end{array}$ & $\begin{array}{c}\text { i mono/i mix: } 15 \\
\text { ip mix: } 13\end{array}$ & $\begin{array}{l}114.6 \\
138.2\end{array}$ & $\begin{array}{l}53.0 \\
62.2\end{array}$ & Two-sample & 27 & 0.29 \\
\hline $\begin{array}{l}\text { Climax/intermediate tree species mixtures (i) versus } \\
\text { mixtures of one or two of these species with a pioneer/ } \\
\text { nurse tree species }(p) \#\end{array}$ & $\begin{array}{l}\text { i mix: } 9 \\
\text { ip mix: } 13\end{array}$ & $\begin{array}{l}137.6 \\
178.7\end{array}$ & $\begin{array}{l}63.0 \\
66.8\end{array}$ & Two-sample & 21 & 0.16 \\
\hline $\begin{array}{l}\text { Climax/intermediate tree species (pure and mixed) } \\
\text { versus mixtures of one or two of these species } \\
\text { with a pioneer/nurse tree species \# }\end{array}$ & $\begin{array}{c}\text { i mono/i mix: } 15 \\
\text { ip mix: } 13\end{array}$ & $\begin{array}{l}124.1 \\
178.7\end{array}$ & $\begin{array}{l}61.9 \\
66.8\end{array}$ & Two-sample & 27 & 0.04 \\
\hline
\end{tabular}

* Volume growth of the selected tree species based on the initially planted proportion of tree species 